\title{
lmplementasi Desain Fasilitas Kerja Ergonomis untuk Menurunkan Resiko pada Postur Kerja Duduk Statis
}

\author{
Ign. Luddy Indra Purnama ${ }^{1 *}$, Luciana Triani Dewi ${ }^{2}$, Deny Ratna Yuniartha ${ }^{3}$ \\ $1 *, 2,3)$ Fakultas Teknologi Industri, Program Studi Teknik Industri, \\ Universitas Atma Jaya Yogyakarta \\ Jl. Babarsari No. 43 Yogyakarta 55281 \\ email : luddy@mail.uajy.ac.id, triani.dewi@mail.uajy.ac.id, dena@mail.uajy.ac.id
}

\begin{abstract}
A staticwork position with sitting is common work posture founded in industry, particularly small industry in Indonesia. The problem that review in this paper is the activity of workers sitting static for processing emping in Yogyakarta. Activity done by means sitting on the floor without using table. The activity carried in a continuous long term, so as to cause disease risks muscle and bone especially lower back. Ergonomic work facilities is implemented to solve the work problem with table and chair. The design of work table is developed with concept low cost improvement and consider with secure, health, and convenience of worker. The design process using participatory approach by involving worker to get best design. The result of facilities implementation can be achieved a decrease ih the risk of work. The potential risk of work posture can be repair that shown of the RULA score from 6 to 4, and no more complain the back and waist from worker activity. Kata Kunci: ergonomis, static sitting,work posture, work facility
\end{abstract}

\begin{abstract}
Abstrak
Posisi kerja duduk statis merupakan postur kerja yang umum ditemukan dalam industri, khususnya industri kecil di Indonesia. Permasalahan yang ditinjau dalam makalah ini adalah aktivitas kerja duduk statis pekerja industri kecil pengolah emping di Yogyakarta. Aktivitas dilakukan dengan cara duduk di lantai dengan posisis kaki menyilang tanpa menggunakan meja. Aktivitas dilakukan dalam jangka lama secara terus menerus sehingga menimbulkan resiko penyakit otot dan tulang khususnya punggung bagian bawah. Fasilitas kerja ergonomis diimplementasikan untuk menyelesaikan permasalahan resiko kerja berupa meja dan kursi kerja. Rancangan meja kerja dikembangkan dengan konsep low cost improvement dengan tetap memperhatikan aspek keamanan, kesehatan dan kenyamanan pekerja. Proses perancangan menggunakan pendekatan partisipatif dengan melibatkan pekerja untuk mendapatkan desain terbaik. Hasil implementasi fasilitas kerja dapat dicapai penurunan resiko kerja. Potensi resiko postur kerja terjadi perbaikan yang ditunjukkan dari skor RULA dari 6 menjadi 4 dan tidak ada lagi keluhan punggung dan pinggang pekerja selama beraktivitas.
\end{abstract}

Keywords: ergonomic, duduk statis, postur kerja, fasilitas kerja

\section{Pendahuluan}

Posisi kerja duduk merupakan postur kerja yang umum ditemukan pada industri, khususnya industri kecil. Hasil riset ergonomi menyatakan posisi kerja duduk lebih dipilih untuk digunakan dibanding postur kerja berdiri, terlebih untuk pekerja wanita (Lehto \& Buck, 2008). Postur kerja duduk memberi keuntung-

\footnotetext{
*Korespondensi Penulis
}

an dibanding postur kerja berdiri karena dapat menurunkan beban statis khususnya pada kaki, memungkinkan peredaran darah yang lebih lancar dan tingkat kelelahan yang lebih rendah $(\mathrm{Pu}-$ lat, 1996).

Tidak semua postur kerja duduk aman untuk dilakukan. Duduk statis dalam jangka lebih dari 1,5 jam beresiko terjadi nyeri punggung bawah (low back pain) pada pekerja. Resiko meningkat pada pekerja wanita dan postur tubuh kurus 
(Diana Samara, 2005). Kondisi alas duduk dan cara duduk yang digunakan berpotensi menimbulkan resiko ketidaknyamanan pada postur kerja duduk. Aktivitas duduk dengan alas duduk tebal dan asimetris dalam jangka pendek, sekitar 15 menit beresiko menimbulkan ketidaknyamanan dan penyimpangan postur tulang belakang (Viggiani, Noguchi, Gruevski, De Carvalho, \& Callaghan, 1999). Selama bekerja dalam tempo lama dengan posisi duduk statis, orang cenderung mencari berbagai varian postur duduk untuk mengurangi ketidaknyamanan dan resiko yang dirasakan (Kampa, Kilincsoya, \& Vink, 2011).

Pada aktivitas produksi di industri kecil, dapat ditemukan berbagai macam posisi duduk saat bekerja. Posisi kerja duduk dapat dilakukan dengan menggunakan fasilitas kursi dan meja atau tanpa fasilitas kerja sama sekali. Posisi duduk tanpa fasilitas kerja berarti aktivitas dilakukan dimana pekerja duduk di lantai tanpa kursi dan lantai juga sebagai permukaan kerja, sehingga tidak menggunakan meja. Ragam posisi duduk di lantai antara lain duduk dengan kaki menyilang (crossed leg sitting - CLS) atau duduk dengan tumpuan kaki (heel sitting - HS). Kerja duduk di lantai baik jenis CLS maupun HS akan memberi resiko kelelahan pada otot punggung dan secara khusus nyeri punggung bagian bawah (Areeudomwonga, Puntumetakulb, Kaberc, Wanpen, \& Leelayuwatd, 2012).

Posisi kerja dapat diperbaiki dengan mempertimbangkan penggunaan fasilitas kerja berupa meja dan kursi yang ergonomis. Permukaan kerja (work surface) perlu dirancang sedemikian rupa sehingga pekerja tidak mengalami permasalahan dalam menangani pekerjaan. Area kerja utama harus ditempatkan tepat di depan pekerja untuk menghindari perputaran punggung saat beraktivitas (Bridger, 2003).

Kasus yang ditinjau dalam makalah ini adalah aktivitas kerja duduk statis pekerja industri kecil pengolah emping umbi garut di Yogyakarta. Secara khusus ditinjau postur kerja pada proses pemipihan umbi dimana pekerjaan dilakukan dengan cara duduk di lantai posisi CLS tanpa meja kerja, jadi lantai sebagai permukaan kerja (work surface). Aktivitas ini merupakan proses yang terlama di antara proses yang lain dalam pengolahan emping. Dalam sehari pekerja melakukan proses ini selama lebih kurang 4 (empat) jam secara terus menerus, akibatnya pekerja mengalami keluhan setelah beraktivitas. Keluhan utama yang dirasakan adalah nyeri pinggang dan punggung serta leher. Permasalahan yang dihadapi pekerja tersebut diselesaikan dengan implementasi fasilitas kerja ergonomis.

\section{Metodologi}

Tinjauan awal dilakukan pada aktivitas pekerja dengan evaluasi postur menggunakan lembar kerja Rapid Upper Limb Assessment (RULA) (McAtamney \& Corlett, 1993). Wawancara terhadap pekerja dilakukan untuk mengetahui keluhan anggota badan yang dirasakan pekerja selama beraktivitas.

Analisis teknis dilakukan dengan memperhitungkan dimensi rancangan berdasarkan data antropometri orang Indonesia. Hasil rancangan dilakukan pemodelan manusia dengan menggunakan perangkat lunak CATIA. Diagram alir metodologi ditunjukkan pada Gambar 1.

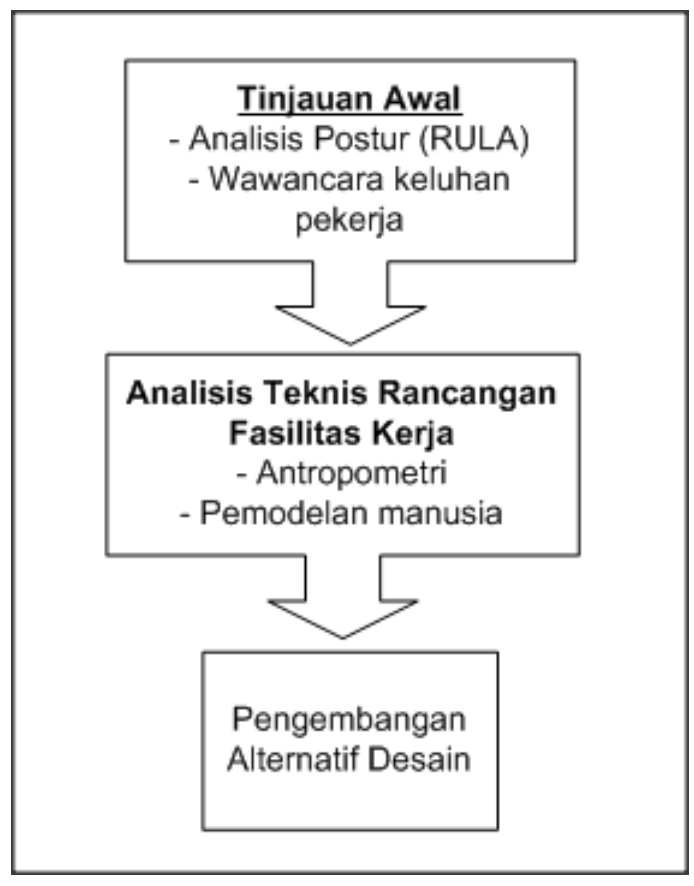

Gambar 1: Metodologi Penelitian

Konsep perbaikan yang sesuai untuk industri kecil dan menengah (IKM) khususnya di negara berkembang adalah perbaikan yang memperhatikan keterbatasan dalam hal finansial atau low cost improvement (UNCTAD, 2001). Rancangan produk untuk perbaikan IKM sebaiknya fokus pada penyelesaian masalah yang dihadapi IKM dan diterapkan dengan kreativitas (Weenen, 2000). Rancangan fasilitas kerja ergonomis dikembangkan dengan konsep low cost improvement dengan tetap mengutamakan aspek keamanan, kesehatan dan kenyamanan pekerja. Proses perancangan menggunakan pendekatan 
partisipatif dengan melibatkan pekerja untuk mendapatkan alternatif rancangan terbaik dengan metodologi ditunjukkan pada Gambar 2. Pengembangan alternatif desain dilakukan oleh pelaku usaha dan tim perancang. Berdasarkan alternatif-alternatif yang ada dilakukan pengambilan keputusan dengan mempertimbangkan kriteria atribut-atribut produk meliputi: material, proses pengerjaan, biaya produksi dan perawatan produk. Pemilihan alternatif dilakukan dengan brainstorming antara tim perancang dan pelaku usaha dengan matriks keputusan.

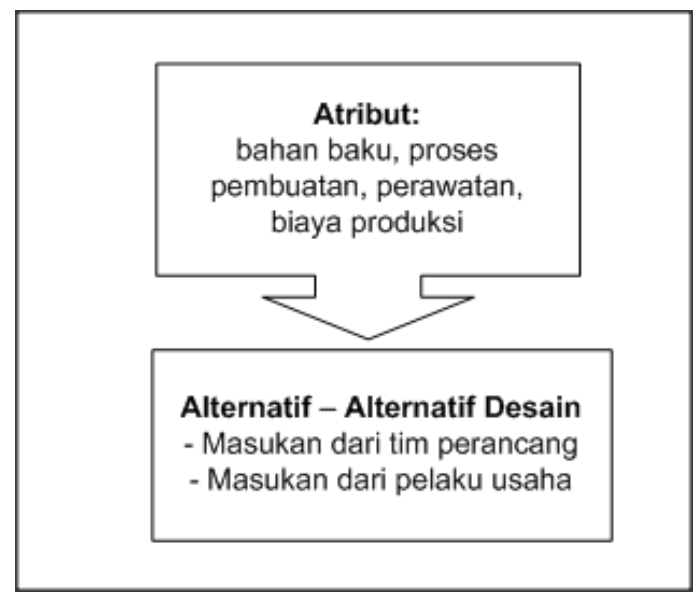

Gambar 2: Metodologi Pengembangan Desain

\section{Hasil dan Pembahasan}

\subsection{Analisis Postur Kerja Awal}

Tinjauan postur pekerja pengolah emping dilakukan dengan mendokumentasikan postur kerja yang umumnya digunakan oleh pelaku usaha. Berdasarkan hasil observasi, diketahui postur umum yang digunakan dalam proses pemipihan umbi adalah duduk di lantai dengan posisi CLS, dengan alas duduk tipis dan tanpa meja kerja seperti ditunjukkan pada Gambar 3. Evaluasi postur dengan lembar kerja RULA memberi hasil skor RULA sebesar 6 yang berarti dibutuhkan investigasi dan perubahan segera. Skor kritis pada bagian tubuh punggung (trunk), dimana punggung membungkuk ke arah depan dengan sudut $20^{\circ} 60^{\circ}$.

Wawancara keluhan pekerja memberi hasil yang sesuai dengan skor RULA. Prevalensi keluhan pekerja terbesar adalah punggung dan pinggang merasa pegal-pegal selama beraktivitas.

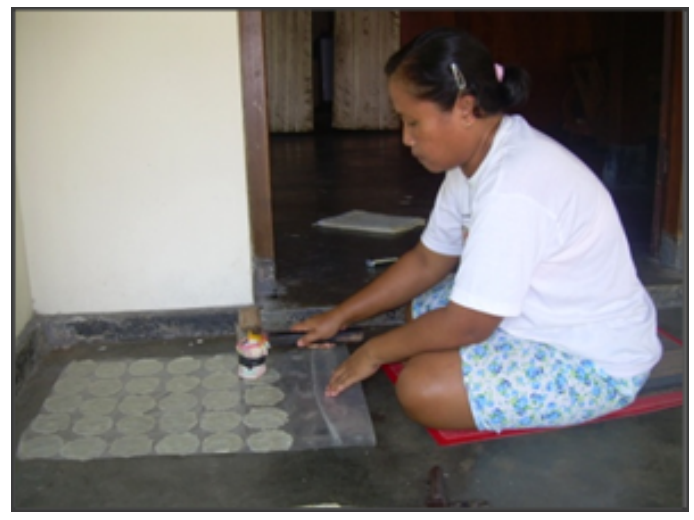

Gambar 3: Postur Kerja Proses Pemipihan Umbi

\subsection{Pengembangan Desain Fasilitas Kerja}

Berdasarkan hasil evaluasi postur dengan RULA menunjukkan perlunya perbaikan postur kerja, khususnya bagian punggung. Perbaikan postur kerja dilakukan dengan implementasi fasilitas kerja yaitu meja dan kursi untuk proses pemipihan umbi. Konsep low cost improvement diterapkan dengan penggunaan fasilitas kerja yang ada yang layak untuk digunakan yaitu kursi yang dimiliki pelaku usaha. Kursi kerja yang digunakan dari material plastik, tanpa sandaran dengan tinggi dudukan $37 \mathrm{~cm}$ dari lantai.

Rancangan meja kerja dikembangkan untuk menghasilkan postur kerja yang lebih baik dari postur kerja sebelumnya. Meja kerja dirancang untuk digunakan dengan posisi kerja duduk di kursi tanpa sandaran dengan tinggi alas duduk $37 \mathrm{~cm}$ dari lantai. Analisis antropometri digunakan untuk menentukan dimensi meja kerja. Tinggi permukaan meja mempertimbangkan data antropometri tinggi siku duduk persentil 5, yaitu 30,19 cm (SD 6,21) (antropometriindonesia.com) ditambah dengan tinggi alas duduk $37 \mathrm{~cm}$. Maka ketinggian alas meja dari lantai adalah 67,19 cm (SD 6,21). Dengan mempertimbangkan proses yang dilakukan pada permukaan meja, maka ditentukan tinggi permukaan meja $60 \mathrm{~cm}$ dari lantai. Panjang dan lebar permukaan meja disesuaikan dengan alas yang digunakan dalam proses pemipihan umbi yaitu $80 \mathrm{~cm} \times 50 \mathrm{~cm}$. Dengan kelonggaran ditentukan ukuran panjang dan lebar permukaan meja $90 \mathrm{~cm} \times 60 \mathrm{~cm}$. Dikembangkan desain meja dan kursi kerja dalam bentuk gambar teknis dengan pemodelan manusia menggunakan perangkat lunak Catia V6 seperti ditunjukkan pada Gambar 4.

Berdasarkan konsep desain yang telah di- 


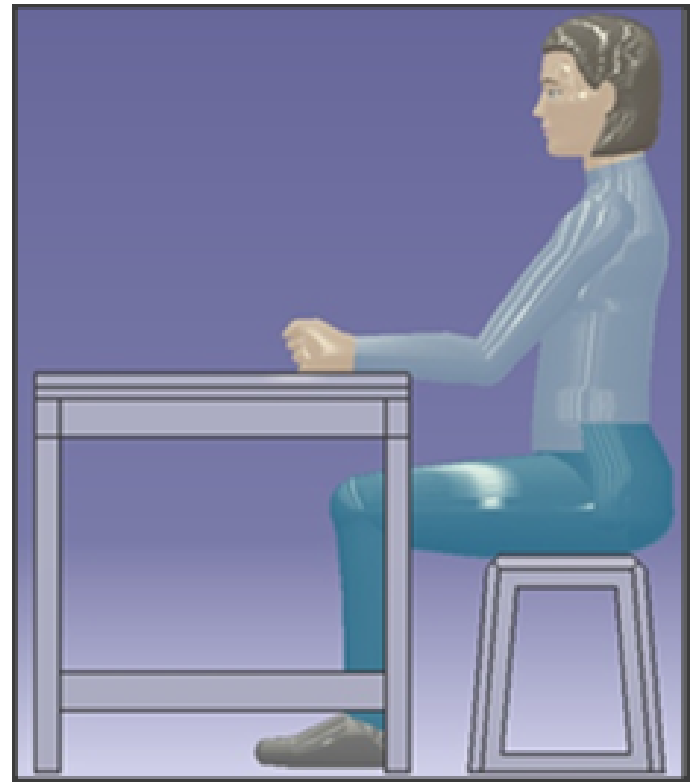

Gambar 4: Pemodelan Manusia Pada Desain Fasilitas Kerja

tentukan dilakukan pengembangan alternatif rancangan meja kerja. Kelompok usaha dan tim perancang berhasil mengembangkan 2 (dua) jenis alternatif rancangan meja, yaitu: (1) meja dengan material cor beton dengan tulang rangka besi dilapisi keramik pada permukaan atas dan samping (Gambar 5a), dan (2) meja dengan material kayu dengan alas permukaan batu pualam (Gambar 5b).

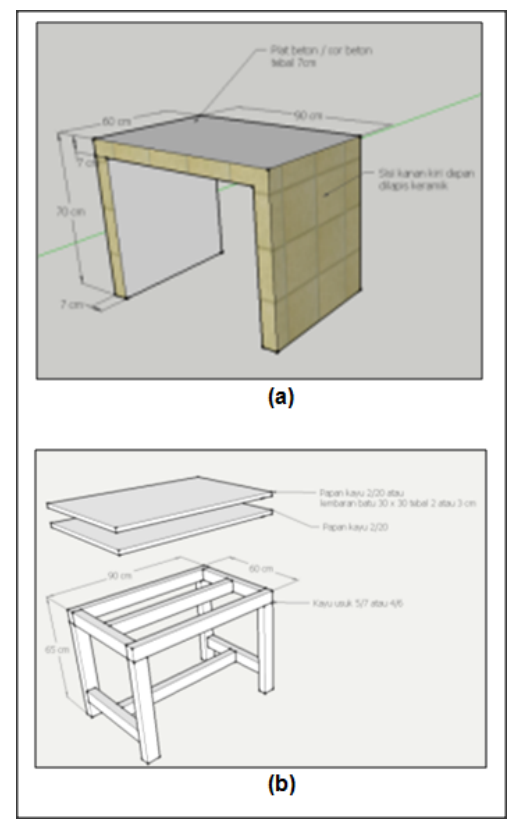

Gambar 5: Alternatif Rancangan Meja Kerja
Matriks keputusan digunakan untuk menentukan alternatif desain yang dipilih berdasarkan brainstorming. Atribut yang dipertimbangkan meliputi: bahan baku, proses pembuatan, perawatan dan biaya produksi.

Berdasarkan matriks keputusan, ditentukan alternatif terpilih adalah desain jenis kedua dengan material kayu yang menghasilkan skor tertinggi seperti ditunjukkan pada Tabel 1.

Tabel 1: Matriks Keputusan Alternatif Desain

\begin{tabular}{|c|c|c|c|c|}
\hline \multirow{2}{*}{ Atribut } & \multicolumn{2}{|l|}{ Desain(1) } & \multicolumn{2}{|l|}{ Desain (2) } \\
\hline & Ket. & Skor & Ket. & Skor \\
\hline $\begin{array}{l}\text { Bahan } \\
\text { baku }\end{array}$ & $\begin{array}{l}\text { Berat, meja tidak bisa } \\
\text { dipindah-pindah, } \\
\text { permukaan tidak } \\
\text { tahan kompresi } \\
\text { kontinyu }\end{array}$ & 0 & $\begin{array}{l}\text { Ringan, meja bisa } \\
\text { dipindah-pindah, } \\
\text { permukaan tahan } \\
\text { kompresi kontinyu }\end{array}$ & 1 \\
\hline $\begin{array}{l}\text { Proses } \\
\text { pembu- } \\
\text { atan }\end{array}$ & $\begin{array}{lr}\text { Perlu } & \text { keahlian } \\
\text { khusus, } & \text { waktu } \\
\text { pengerjaan } & 2 \text { hari }\end{array}$ & 0 & $\begin{array}{lr}\text { Perlu } & \text { keahlian } \\
\text { khusus, } & \text { waktu } \\
\text { pengerjaan } & 1,5 \text { hari }\end{array}$ & 1 \\
\hline Perawatan & $\begin{array}{l}\text { Tidak perlu per- } \\
\text { awatan khusus, } \\
\text { hanya pembersihan } \\
\text { minimal }\end{array}$ & 1 & $\begin{array}{lr}\text { Perlu } & \text { perawatan } \\
\text { khusus } & \text { untuk } \\
\text { menjaga } & \text { dari } \\
\text { basah/lembab } & \text { yang } \\
\text { dihasilkan } & \text { dari } \\
\text { proses pemipihan }\end{array}$ & 0 \\
\hline $\begin{array}{l}\text { Biaya } \\
\text { pembu- } \\
\text { atan }\end{array}$ & $\begin{array}{ll}\text { Lebih mahal karena } \\
\text { butuh } & \text { rangka } \\
\text { besi/baja } & \end{array}$ & 0 & $\begin{array}{l}\text { Lebih murah karena } \\
\text { bisa menggunakan } \\
\text { kayu dan batu lokal } \\
\text { yang lebih murah }\end{array}$ & 1 \\
\hline Skor total & & 1 & & 3 \\
\hline
\end{tabular}

\subsection{Evaluasi Hasil Implementasi}

Hasil rancangan meja kerja selanjutnya diproduksi oleh masyarakat setempat dan dilakukan implementasi penggunaan pada proses pemipihan. Evaluasi hasil rancangan dilakukan dengan melakukan evaluasi postur RULA pada pekerja saat beraktivitas menggunakan fasilitas kerja yang diimplementasikan (Gambar 6).

Analisis dengan lembar kerja RULA pada aktivitas pemipihan umbi dengan menggunakan fasilitas kerja meja dan kursi menghasilkan skor RULA 4 (investigasi lebih lanjut diperlukan dan perubahan mungkin dibutuhkan). Dengan implementasi fasilitas kerja ergonomis, skor RULA untuk lengan atas, leher dan punggung menunjukkan perbaikan dibandingkan postur awal tanpa fasilitas kerja. Skor RULA 1 atau 2 (dapat diterima) tidak dapat dicapai karena aktivitas ini dilakukan statis dalam jangka lama. Berdasarkan wawancara terhadap pekerja diperoleh hasil prevalensi keluhan punggung dan pinggang selama beraktivitas tidak dirasakan lagi.

\section{Kesimpulan dan Saran}

Implementasi fasilitas kerja ergonomis berupa meja dan kursi pada aktivitas kerja duduk statis 


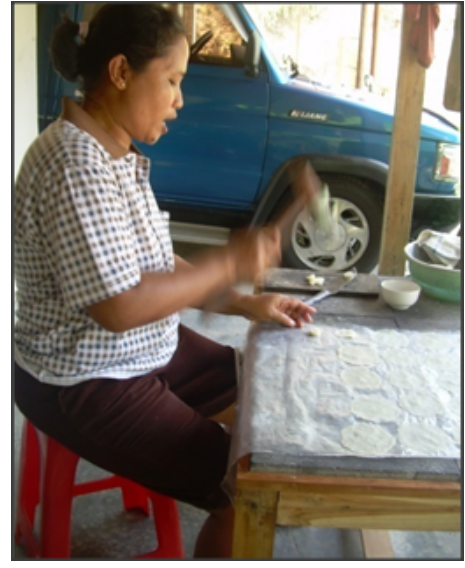

Gambar 6: Implementasi Fasilitas Kerja

dapat menurunkan resiko gangguan muskuloskeletal pada pekerja. Untuk pengembangan usaha dengan skala produksi lebih besar disarankan untuk merancang alat mekanik sederhana.

\section{Daftar Pustaka}

Areeudomwonga, P., Puntumetakulb, R., Kaberc, D. B., Wanpen, S., \& Leelayuwatd, N. (2012). Effects of Handicraft Sitting Postures on Lower Trunk Muscle Fatigue. Ergonomics , 55 (6), 693703.

Bridger, R. (2003). Introduction to Ergonomics. New York: Taylor \& Francis Inc.

Diana Samara, B. B. (2005). Duduk Statis Sebagai Faktor Risiko Terjadinya Nyeri Punggung Bawah Pada Pekerja Perempuan. Universa Medicina , 24 (2).

Kampa, I., Kilincsoya, \& Vink, P. (2011). Chosen Postures During Specific Sitting Activities. Ergonomics , 54 (11), 10291042.

Lehto, M. R., \& Buck, J. R. (2008). Introduction to Human Factors and Ergonomics for Engineers. New York: Taylor and Francis Group.

McAtamney, \& Corlett, N. (1993). RULA: a survey method for the investigation of. Applied Ergonomics , 24 (2), 91-95.

Pulat, B. M. (1996). Fundamentals of Industrial Ergonomics. Illinois: Waveland Press Inc.

Sekaran, U. (2010). Research Methods for Business. Chichester: John Wiley \& Sons.

UNCTAD. (2001). Improving Competitiveness of SMEs in Developing Countries. Geneva: United Nations.
Viggiani, D., Noguchi, M., Gruevski, K. M., De Carvalho, D., \& Callaghan, J. P. (1999). Seated Work Postures for Manual, Visual and Combined Tasks. ERGONOMICS , 42 (8), 1060- 1086.

Weenen, H. V. (2000). Product Desig-Practical Examples of SMEs. Sustainable Development, SMEs and New Enterprises (hal. 37-38). Dublin: European Foundation for The improvement of Living and Working Conditions. 